\title{
Urpo Harva ja hyvinvointivaltio
}

\author{
JAN SJÖBERG
}

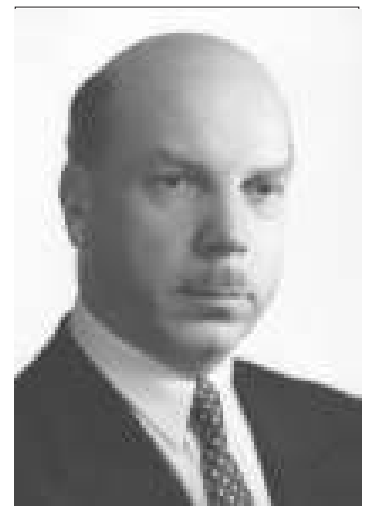

Urpo Harva (1910-1994)
Kansansivistysopin suomalainen uranuurtaja Urpo Harva (19101994) on legenda hänen kanssaan tekemisissä olleiden ihmisten, ennen muuta hänen entisten oppilaittensa, mielikuvissa. Ajattelullaan Harva loi perustan myöhemmälle aikuiskasvatustieteelle. Mitä Harva mahtaisi ajatella aikuiskasvatustutkimuksen nykytrendeistä? Åbo Akademin akatemialehtori Jan Sjöberg heittäytyy ajatusleikkiin Harvan yhteiskunnallista ja humanistista ajattelua tulkitsemalla.
2 ajattelija. Hänen syntymästään on kulunut 100 vuotta. Harvan kirjallinen tuotanto on laaja, teoreettisesti ja filosofisesti kiinnostava sekä aina ajankohtainen. Häntä voidaan luonnehtia yleispedagogiksi, aikuiskasvattajaksi ja yhteiskuntafilosofiksi. Voimme varmasti löytää myös muita määritelmiä, joilla häntä voisi kuvailla, mutta ennen kaikkea nämä ulottuvuudet hänen ajattelussaan ovat kiehtoneet minua. Tässä artikkelissa olen valinnut lähtökohdaksi hänen kirjansa "Ihminen hyvinvointivaltiossa" vuodelta 1964 ja suhteuttanut sen nykyiseen yhteiskunnalliseen kehitykseen. Mitä Harva ajattelisi nykyisistä trendeistä sivistyksen ja koulutuksen aloilla?

Kirjassaan Harva polemisoi hyvinvointivaltiota vastaan sillä perusteella, että hyvinvointivaltion kehittyminen huoltovaltioksi voi uhata perustavanlaatuisia humanistisia arvoja. Hän näki hyvinvointivaltiossa uhan siinä, että siitä saattoi kehittyä kaiken yksilöllisyyden tukahduttava, huolenpitoon keskittyvä massayhteiskunta. Harvan mukaan massayhteiskunta on ihmisluonnon vastainen, koska se tukahduttaa yksilöllisyyden ja vapauden. Kuinkas sitten kävikään? Miksi hyvinvointiyhteiskunnasta tuli markkinasuuntautunut kilpailuyhteiskunta huoltovaltion sijasta?

Yhteiskunta- ja koulutuspolitiikan tarkoituksen voisi tänään odottaa olevan koulutuksen laadun, yksilön elämänlaadun sekä koulun, työelämän ja yhteiskunnan demokratisoiminen yleensä. Hyvät tavoitteet, jotka ovat vahvasti sidoksissa perinteisen hyvinvointivaltion ideaan, ja joiden lähtökohta on tasa-arvoajattelu.

Tämän päivän kehityssuunta on kuitenkin toisenlainen. Yhteiskunnallisen toiminnan keskittämisestä on tullut ajan sävel. Tämän päivän eurooppalainen ja kansallinen koulutuspolitiikka on laajalti alistettu markkinataloudelliselle ajattelulle ja uusliberaalille yhteiskuntaprojektille. Uusliberaalin koulutuspolitiikan lähtökohta tuntuu olevan se, että koulu ja koulutus eivät ole riittävän laadukkaita ja että tehokkuutta voi parantaa. Tämä voidaan saada aikaan kilpailua lisäämällä. Suhteessa taloudellisiin panoksiin tuotetaan ja saadaan aikaan liian vähän. Ajatellaan, että yhteiskunnan rakenteissa on liian paljon ilmaa, ja silloin voidaan oikeutetusti vaatia enemmän opettajilta ja henkilöiltä, jotka tekevät työtä koulun ja koulutuksen alalla. Tehokkuusajattelun nimissä on jopa esitetty, että opettajien palkat voitaisiin kytkeä oppilaiden mitattavissa oleviin suorituksiin. Kaikkien pitää saada aikaan enemmän, tulla vielä tehokkaammiksi ja pysyä pitempään työelämässä. Koulutuksen avulla halutaan tasoittaa työelämän kriisejä. Koulutus alistetaan yhä selvemmin tuotantoelämän intresseille. Siitä syystä oppimista tarkastellaan elämänmittaisesta näkökulmasta. Elinikäisen oppimisen pitää palvella työmarkkinoiden tarpeita. Elinikäinen oppiminen ei ole vain pedagoginen 
ajattelutapa vaan koko työmarkkinoiden suunnittelun perusta. Elinikäisen oppimisen alistamista työmarkkinoille ei Harva olisi voinut hyväksyä. Humanismi on joutunut väistymään talouden tieltä uudessa koulutusajattelussa. Harva näki vaaran siinä, että yksipuolisesti painotetaan tuotantoelämän etuja, ja hän toteaa, että "tuotantouskonnon ideologiaan kuuluu työn merkityksen yliarvioiminen, jopa suorastaan sen jumaloiminen". Siinä mielessä Harva kykeni ennustamaan työelämän tulevan kehityksen. Harvan sanoin voimme myös tänään todeta, että tarvitsemme "humanistista työnfilosofiaa, jossa selvitetään työn asema ja arvo ihmiselämän kokonaisuudessa". Työhön sisältyy toisin sanoen suuri yksilöllinen kasvupotentiaali, jota yhteiskunnan nykyinen kehitys ei saa vaarantaa.

Paradoksaalista nykyisessä koulutuspolitiikassa on se, että laadun yksipuolinen painottaminen suhteessa taloudellisiin tekijöihin voi johtaa työvoiman laadun heikentymiseen. Aivan liian kapeaalainen erikoistuminen voi johtaa siihen, että kokonaisnäkemys yhteiskunnasta, kulttuurista ja työelämästä tulee epäselväksi. Se, että korostetaan vain tehokkuutta, johtaa yksilön kykyjen, valmiuksien ja koko suoritustason alenemiseen. Kapea-alainen vain tiettyjen ominaisuuksien korostaminen voi johtaa tämäntyyppiseen heikentymiseen. Silloin olemme peruuttamattomasti leiponeet systemaattisen virheen nykyisen koulutuspolitiikan sisään. Ja kaikki tapahtuu jatkuvasti laadukkuuden nimissä.

On syytä huomata heikentymisen riskit, jos myös peruskoulun perusajatus jätetään ottamatta huomioon. Yleissivistyksellä on arvo sinänsä kuten Harva on tähdentänyt. Harvat ovat kai kuvitelleet, että nykyinen laatuajattelu voi johtaa työvoiman tason heikkenemiseen. Laadun varmistamiseksi on kehitetty erilaisia yhteiskunnallisia rakenteita. Halutaan mitata koulutuksen laatua ja arvioida yksilöiden kykyjä, valmiuksia ja suorituksia. Mutta uusliberaalissa ajattelutavassa tulee laadun varmistamisesta vain legitiimi menetelmä koulutusjärjestelmän sisällä tapahtuvan toiminnan alasajamiseksi. Kouluja ja erilaisia koulutuksia saatetaan asettaa paremmuusjärjestykseen ja vähemmän tehokkaat karsia pois, mikäli ne eivät toteuta mitattavissa olevia laatukriteerejä. Laatuajattelusta tulee tehokkain väline koulutuksen alasajoon kaikilla tasoilla peruskoulutuksesta aikuiskasvatukseen. Kuinka sitten puolustaa koulutuspolitiikkaa, jonka lähtökohtana ovat sellaiset käsitteet kuin demokratia, tasa-arvo, elämänlaatu ja hyvinvointi? Olen sitä mieltä, että laadun on ensisijaisesti oltava sidoksissa näihin hyvinvointivaltioon liittyviin käsitteisiin. Inhimillinen kasvu on ensisijaista. Inhimillisestä ihmisestä tulee kasvatuksen päämäärä, palatakseni jälleen Harvaan.

Meidän on jatkuvasti työskenneltävä inhimillisemmän koulun ja inhimillisemmän työelämän puolesta. Tähän Harva meitä kehottaisi myös tänä päivänä. Yleissivistyksen pitää saada takaisin se kunniapaikka, jonka se ansaitsee. Kaikkien yksilöiden pitää voida osallistua sosiaalisen kehityksen ohjaamiseen ja yksilöllä pitää itsellään olla mahdollisuus vaikuttaa omaan työhönsä ja elinehtoihinsa ja parantaa niitä. Tällaisia ominaisuuksia on ollut siinä yhteiskunnassa, joka nyt on rapautumassa ja jonka sallitaan rapautua. Kenen mielestä tämä on laadukkuutta? Laadukkuus on inhimillinen näkökohta, ei taloudellinen yksikkö.

Kun on kyse aikuiskoulutuksesta on meidän jatkuvasti avarrettava ihmisen sosiaalisen elämän rajoja. Vapaan sivistystyön pitää edelleen olla paik$\mathrm{ka}$, jossa uusia taitoja, valmiuksia ja asenteita voidaan kehittää. Koko koulutusjärjestelmän kehityksen pitää tapahtua tasa-arvisessa ja demokraattisessa hengessä. Hyvinvointivaltion hengessä. Vapaus, tasa-arvo ja demokratia ovat ajattomia käsitteitä ei vain aikuiskasvatuksen kehittämisessä vaan koko koulutusjärjestelmän kehittämisessä. Koulutuksella voimme luoda motivaation, valmiuden ja strategiat yhteiskunnan, kulttuurin ja työelämän ohjaamiseen ja hallintaan. Koulutus on sosiaalinen instituutio, jolla kehitetään tietoisuuden inhimillistä puolta tehokkuuden sijasta.

Jos koulun ja aikuiskoulutuksen tulee olla viihtyvyyden ja kehityksen tyyssija, pitää inhimilliset näkökohdat nostaa voimakkaammin esiin. On olemassa sisäänrakennettu riski, että markkinasuuntautuneesta kilpailuyhteiskunnasta kehittyy myös massayhteiskunta. Näemme sen, että myös täällä tasapäistäminen lisääntyy vapauden kustannuksella. Markkina-arvot valtaavat alaa ja inhimilliset arvot pakotetaan taka-alalle.

Mitä Harva sanoisi tämän päivän yhteiskunnallisesta kehityksestä? Luulen, että hän puolustaisi hyvinvointiyhteiskuntaa. Uusliberaali ajattelu uhkaa perustavanlaatuisia yksilöllisiä arvoja, kun yksilöiden välinen kilpailu lisääntyy. Yhteiskunta, jota leimaa kilpailu ja yksipuolinen tehokkuusajattelu, ei ole inhimillinen yhteiskunta.

Käännös ruotsin kielestä: Ritva Kontro 